\title{
The Potential Use of Cassava Peel for Treatment of Mine Water in Mozambique
}

\author{
Estêvão A. Jr. Pondja1, Kenneth M. Persson'1, Nelson P. Matsinhe² \\ ${ }^{1}$ Department of Building \& Environmental Technology, Lund University, Lund, Sweden \\ ${ }^{2}$ Department of Civil Engineering, Eduardo Mondlane University, Maputo, Mozambique \\ Email: estevao.pondja@tvrl.lth.se,tindjombo@gmail.com
}

How to cite this paper: Pondja Jr., E.A., Persson, K.M. and Matsinhe, N.P. (2017) The Potential Use of Cassava Peel for Treatment of Mine Water in Mozambique. Journal of Environmental Protection, 8, 277289.

https://doi.org/10.4236/jep.2017.83021

Received: January 13, 2017

Accepted: March 13, 2017

Published: March 16, 2017

Copyright $\odot 2017$ by authors and Scientific Research Publishing Inc. This work is licensed under the Creative Commons Attribution International License (CC BY 4.0).

http://creativecommons.org/licenses/by/4.0/

\begin{abstract}
In the last decade, Mozambique became one of the top coal producers in Africa. The coal mines are in Moatize district in the center of the country, inside the lower Zambezi river basin. Pollution due to mining activities has negative impacts in agriculture, fishing, water supply, and presents risks to public health. Mozambique is one of the largest cassava producers in the world. More than 1.5 million tons of cassava peel are generated in the country and this agrowaste is discarded. The aim of this study is to discuss the possibility of using cassava peel to treat mine water. Cassava peel can be used as carbon sources for sulfate reducing bacteria in bioremediation, as an adsorbent and as a filter medium. An integrated method is proposed for treatment of mine water in Moatize. It was suggested that applying cassava peel generated in developing countries for treatment of mine water could be a good solution to protect the environment against mining pollution.
\end{abstract}

\section{Keywords}

Cassava Peel, Bioremediation, Adsorption, Filtration, Mine Water

\section{Introduction}

Cassava peel is an agro-industrial waste that is discarded in Mozambique; yet it could be used in the treatment of mine water to remove metals and sulfate. Cassava peel could be used as carbon source in bioremediation of mine water, as an adsorbent in adsorption and as a filter medium for filtration of mine water. Implementing this method, metals, sulfates and cassava peel (agricultural waste) would be treated simultaneously, thus, avoiding pollution. Biological treatment of mine water using sulfate reducing bacteria (SRB) to remove sulfate and metals is a promising alternative treatment due to low cost and better quality of sludge compared to conventional treatment methods [1]. Adsorption and filtration of mine 
water using lignocellulosic material (e.g. cassava peel) is very effective in removing metals at low concentration compared to conventional methods at large scale [2]. Developing countries cannot afford much budget to protect their local environment and bioremediation [3], adsorption [2] and filtration [4] seem to be economical strategies that, if applied properly, can be viable solutions for mine water treatment in, for instance, Moatize (Mozambique).

Surface mining has been used in Moatize to exploit coal which results in the generation of waste rock pile, dust and mine water. The coal production in Mozambique increased significantly since 2011 due to start of operation of the first multinational coal mining company operating in Mozambique (Figure 1). After 2011, other multinational mining companies came and the production of coal increased, as illustrated in Figure 1. Increasing coal production means that waste rock piles, dust and mine water will also increase. Infiltration of rain water in waste rock piles results in the generation of mine water which normally contain metals, metalloids and sulfate that can be emitted to the surrounding water resources. During coal extraction, pits are dogged and groundwater flows out. Water is pumped to a tailing dam where sedimentation takes places. Treated water from the tailing pond is used for dust suppression and other parts are discharged to the environment.

Acid mine drainage (AMD) is one of the most serious environmental pollution problems in mining industry around the world [5]. The main source of AMD is waste rock pile and tailings that are generated during mining activities [6]. The acidic mine water that comes from waste rock pile can contain high concentration of sulfate and toxic metals which can damage surface and groundwater



Figure 1. Mineral coal production in Mozambique from 2009 to 2015 [7]. 
and it also represents a risk for human health [8]. According to World Health Organization the concentration of sulfate in drinking water should not exceed 500 $\mathrm{mg} / \mathrm{L}$, because above that limit, it can cause diarrhea and dehydration [9]. The Environmental Protection Agency (EPA) from United States recommends a maximum of $250 \mathrm{mg} / \mathrm{L}$ of sulfate for drinking water [10]. Sulfate, when released to anaerobic environment, can be reduced to extremely toxic hydrogen sulfide [11].

Active treatment is conventionally used for treatment of mine water and its aim is to remove pollutants by chemical and physical process (filters or membranes) [12]. It is based on chemical addition in mine water to raise the $\mathrm{pH}$ and precipitate insoluble metal complex that are formed. Metals and sulfate can also be removed by physical treatment such as nan-filtration, ionic exchange and reverse osmosis. These methods can remove metals and sulfate very efficiently, but they demand high energy and large chemical consumption, which make them very expensive [13]. The other disadvantage of these methods is the generation of bulk sludge and brine [14].

Bioremediation of mine water using SRB seems to be an attractive technology to treat polluted mine water, because it is economically viable and environmentally friendly [15]. SRB removes acidity from mine water, metals and sulfate. Metals that precipitate during the treatment can be recovered. In this process, organic matter $\left(\mathrm{CH}_{2} \mathrm{O}\right)$ is used as carbon source (electron donor) by SRB to reduce sulfate (electron acceptor) to hydrogen sulfide and generate alkalinity under anaerobic condition, as shown in Equation (1). The produced hydrogen sulfide reacts with dissolved metals, and metal sulfides with low solubility are generated (Equation (2)). The alkalinity that is produced in the process is used to neutralize the acidity [14].

$$
\begin{gathered}
2 \mathrm{CH}_{2} \mathrm{O}+\mathrm{SO}_{4}^{2-} \rightarrow \mathrm{H}_{2} \mathrm{~S}+2 \mathrm{HCO}_{3}^{-} \\
\mathrm{H}_{2} \mathrm{~S}+\mathrm{M}^{2+} \rightarrow \mathrm{MS}_{(\mathrm{S})}+2 \mathrm{H}^{+}
\end{gathered}
$$

where: $\mathrm{M}^{2+}$ are metals: $\mathrm{Cu}^{2+}, \mathrm{Zn}^{2+}, \mathrm{Fe}^{2+}, \mathrm{Pb}^{2+}, \mathrm{Ni}^{2+}, \mathrm{Co}^{2+}, \mathrm{Cd}^{2+}$, or $\mathrm{Ag}^{+}$.

Mine water has very low content of organic matter which is why extra supply source of organic matter is needed. Low molecular weight compounds like organic acids (lactate, formate, acetate, and propionate) and alcohols (ethanol, methanol, and glycerol) are preferable carbon source for SRB [16]. There are others cost-effective electron donors that were used by researchers in laboratory scale, namely: hydrogen coupled with $\mathrm{CO}_{2} / \mathrm{CO}$, glucose, sucrose, molasses, plant material (mushroom, wood chips, sawdust, rice straw), animal manure [17]. According to the consulted literature, cassava peel has not yet been used as carbon source for SRB in the treatment of contaminated mine water.

Cassava (Manihotesculentacrantz) is mostly used in tropical regions as a staple food because it is tolerant to drought and it is productive in poor soils. Africa is the continent with the highest cassava production (230 million tons in 2012 which correspond to $53 \%$ of world production). Mozambique was ranked 5 th in Africa and 8th in the world regarding to cassava production [18].

In Mozambique, there is a very limited usage of cassava for industrial purpos- 
es, because the sector is oriented toward family consumption. Most of produced cassava in Mozambique is processed by individual households to produce traditional food (rale and ugali) or it is sold fresh in local markets for domestic consumption. The potential for industrialization of cassava that Mozambique has is not yet being exploited due to lack of investment in the sector. The main cassava products that can be produced at industrial level are: high quality cassava flour, cassava chips, starch and ethanol. To date, in Mozambique, there is only one beer company called "Cervejas de Mocambique (CdM)" that produces beer called "Impala" that derives from cassava. The company was launched in 2011 and currently, it uses 315 tons of fresh cassava weekly. The cassava is supplied by farmers located in Nampula and Inhambane province [19]. The cassava production in Mozambique increased a lot due to introduction of a beer company in 2010 that produce beer from cassava (Figure 2).

According to [20], cassava peel correspond to $10 \%-20 \%$ of total wet weight of fresh cassava, meaning that it has a potential to be used in biotechnology and in industrial scale when availability is not a problem. The chemical composition of cassava peel is presented in Table 1, in percentage. Cassava peels are rich in carbohydrate (cellulose and hemicellulose) and lignin, as shown in Table 1. The differences in cassava peel composition in Table 1 are probably due to different climatic conditions, soil fertility and type, and harvesting period [21].

To avoid metal and sulfate pollution in Mortize's water resources due to coal mining activities, it is necessary to treat the mine water that comes from the coal washing process, pits, waste pile drainage, tailing dams, and surface runoff. The



Figure 2. Cassava production in Mozambique [18]. 
Table 1. Chemical composition of cassava peel in percentage.

\begin{tabular}{cccccc}
\hline Hemicellulose & Cellulose & Proteins & Lignin & Ash & Reference \\
\hline 32.36 & 9.71 & 3.7 & 16.89 & 11.38 & {$[21]$} \\
27.0 & 14.0 & 3.5 & 11.0 & 7.0 & {$[22]$} \\
23.40 & 14.17 & 5.29 & 10.88 & 3.7 & {$[23]$} \\
\hline
\end{tabular}

only treatment method that is used in coal mines that are in Moatize is sedimentation. In sedimentation process, dissolved metals and sulfate are not removed and they end up in nearby water resources. It is urgent to find cost-effective treatment methods for mine water in Moatize in order to convince the coal mining companies to apply those technologies to avoid water pollution. The aim of this paper is to describe the cassava's potential as carbon source for SRB, adsorbent and filter medium in the treatment of mine water, and suggest a costeffective treatment method for mine water in Moatize.

\section{Mine Water Treatment Options for Moatize}

In this section, the potential application of cassava peel for treatment of mine water will be described. In the coming section, SRB, adsorption and filtration will be discussed for mine water treatment.

\subsection{Using Cassava Peel as Carbon Source for Bioremediation}

There are no published studies where cassava peel was applied as carbon source for treatment of mine water. The choice of carbon source is vital for the economy of the process. In active bioreactor, liquid or gaseous carbon source is preferred, because continuous operation is needed [24]. Ethanol has been successfully used as carbon source for treatment of mine water with SRB in a complete-mix reactor with a volumetric and specific sulfate reduction rate of $6.6 \mathrm{~g} \mathrm{SO} 42-/(1 . \mathrm{d})$ and $2.8 \mathrm{~g} \mathrm{SO} 42-/(\mathrm{g}$ VSS.d) respectively [25]. The advantages of using ethanol as a carbon source for SRB are its relative cheap price and it is easily converted by SRB, but the disadvantage is its low biomass yield and incomplete oxidation to acetate which lead to effluent with high content of COD [17].

The ethanol production from cassava peel has different steps and the first one is to prepare the cassava peel for the process. In order to increase the availability of sugar that can be hydrolyzed biologically for ethanol production using cassava peel, it is necessary to make a pretreatment in cassava peel biomass to reduce recalcitrance biomass [26]. The polysaccharides (carbohydrates) in cassava peel biomass must be broken down into monosaccharide to increase availability of hydrolysis. Catalyzed steam explosion (CSE) is the preferred method to perform this pretreatment for cassava peel biomass because addition of catalyst in this treatment can increase significantly sugar yields [27]. Steam $(\mathrm{T}=433 \mathrm{~K}$ and $\mathrm{p}=1.5$ $\mathrm{MPa}$ ) is fed into a reactor where it gets in contact with cassava peel for about 5 min and then the pressure is drastically dropped to cause expansion of lignocellulosic matrix in order to cause separation of individual fibers [28]. Since diluted sulfuric acid is inexpensive, it is used as a catalyst which reduces the content of 
xylose up to $90 \%$ contributing for increase in ethanol yield [29]. In the hydrolysis phase, cellulose is broken down into glucose and reducing sugar. Simultaneous sacharification and fermentation (SSF) seem to be the process with best efficiency when enzymatic hydrolysis is carried out during bioethanol production [30].

The procedures for ethanol production and subsequent treatment of mine water are described in the coming section. Cassava in Mozambique can be bought in local markets and from local farmers. The cassava must be washed with clean water and the peel must be removed. Cassava peel contain cyanide and thus, it is necessary to soak it in water for 5 hours to remove cyanide [31] and then dry it in the sun for 7 days to remove moisture content (Figure 3). The dried cassava peel must be chopped and milled to increase surface area for chemical reactions, to increase the digestibility of cellulose and reduce dry matter losses [32]. The grounded cassava peel can be stored in silos for ethanol production or for other uses.

\subsection{Adsorption}

Chemical precipitation, ion exchange, adsorption, ultrafiltration, reverse osmosis, nan-filtration, electro-dialysis, coagulation, flocculation, flotation and electrochemical process are quite used to remove metals and metalloid from wastewater. According to, [33] adsorption has advantages comparatively with the above mentioned methods because it is easy to operate, it is economically feasible, and the design is simple. Adsorption has high metal removal efficiency and adsorbent can be reused [34].

To date, activated carbon is the adsorbent that is most used in the world due to its high efficiency in removing metals and nonmetal pollutants from polluted water. Activated carbon has high surface area, good microporous structure and



(a) Cassava in local market

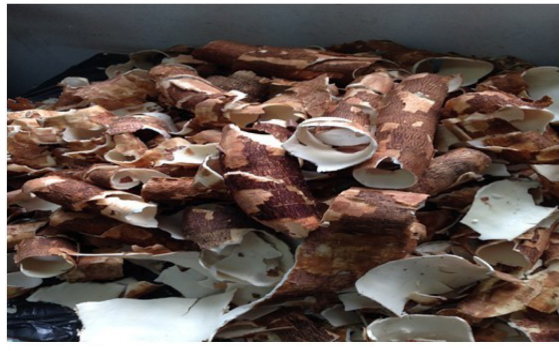

(c) Fresh cassava peel



(b) Removal of peel in the cassava

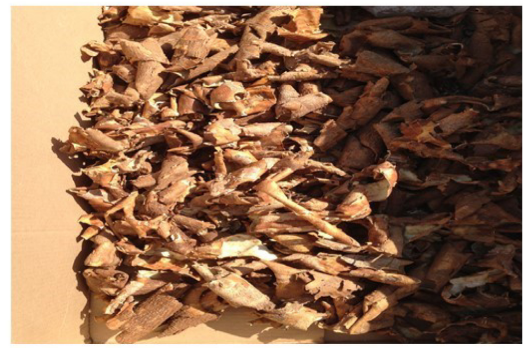

(d) Dried cassava peel by sun

Figure 3. Cassava peel preparation process for silage (Mozambique). 
porosity. For that reason, it can be used in batch and continuous operation [35]. There are other adsorbents that are used for metal sequestration: zeolites, clay, chitosan, red mud, dairy sludge and metal oxides [36]. Due to high costs of commercial activated carbon, researchers are now focused on low cost adsorbents. Cellulosic low cost bio-adsorbents (e.g: agricultural waste) are used to remove metal due to its low economic value, high availability and its potential to treat large scale wastewater. The cellulosic adsorbents that have been used for metal removal are rice husk [37], banana peel [38], wheat straw [39], grape bagasse [40], corn stalk [41], coir pith [42], bel fruit shells [43], corn cob [44], and hemp fibers [45]. The majority of cellulosic waste is constituted by cellulose, hemicelluloses and lignin. Metals from wastewater adhere on the surface. The adsorption capacity of these materials can be improved by chemical and physical treatment [36]. Cassava peel can also be used as adsorbent in the treatment of mine water from coal mine in Moatize. According to [46], cassava peel chemically modified is an excellent adsorbent to remove $\mathrm{Cd}, \mathrm{Pb}$ and $\mathrm{Cr}$. From economic point of view the cassava peel used as bio-sorbent is a sustainable alternative compared with conventional treatment methods, because it can remove effectively metals to very low concentrations at low cost [2]. Research done by Simate \& Ndlovu (2014) about "removal of heavy metals in a packed bed column using immobilized cassava peel waste biomass" concluded that metals can be removed efficiently by cassava peel.

\subsection{Filtration}

Cassava peel can be used as filter medium in passive treatment of mine water. In this low cost treatment process, flow of mine water goes through filter medium (e.g cassava peel) and pollutants are removed. Organic filter material such as lignite [47] and rice husk [48] were used successfully in the removal of metal and sulfate from mine drainage. According to [4], there are some disadvantages in using filter material in large scale, namely: high cost, variable composition of mine water, instability, and risk of leaching hazard substances from filter material. Cassava peel contain cyanide and if appropriate treatment it not done, cyanide can end up in the environment. A pre-treatment of cassava peel would be necessary to remove the cyanide and then use it as filter medium for treatment of mine water.

\section{Integrating Bioethanol Production and Subsequent Treatment of Mine Water}

Figure 4 illustrates mine water treatment scheme. The cassava peel that was previously treated and stored in silos would be fed simultaneously with steam in a reactor to increase ethanol yield as explained before. The fuel that can be used for the boiler could be thermal coal that is produced in Moatize or the bioethanol to avoid usage of fossil fuel. A flash separator could be used to remove by-products (eg. Xylose). The next step would be a pre-hydrolysis of cellulose during 24 hours where cellulose would be reduced into glucose and reduced sugar. 


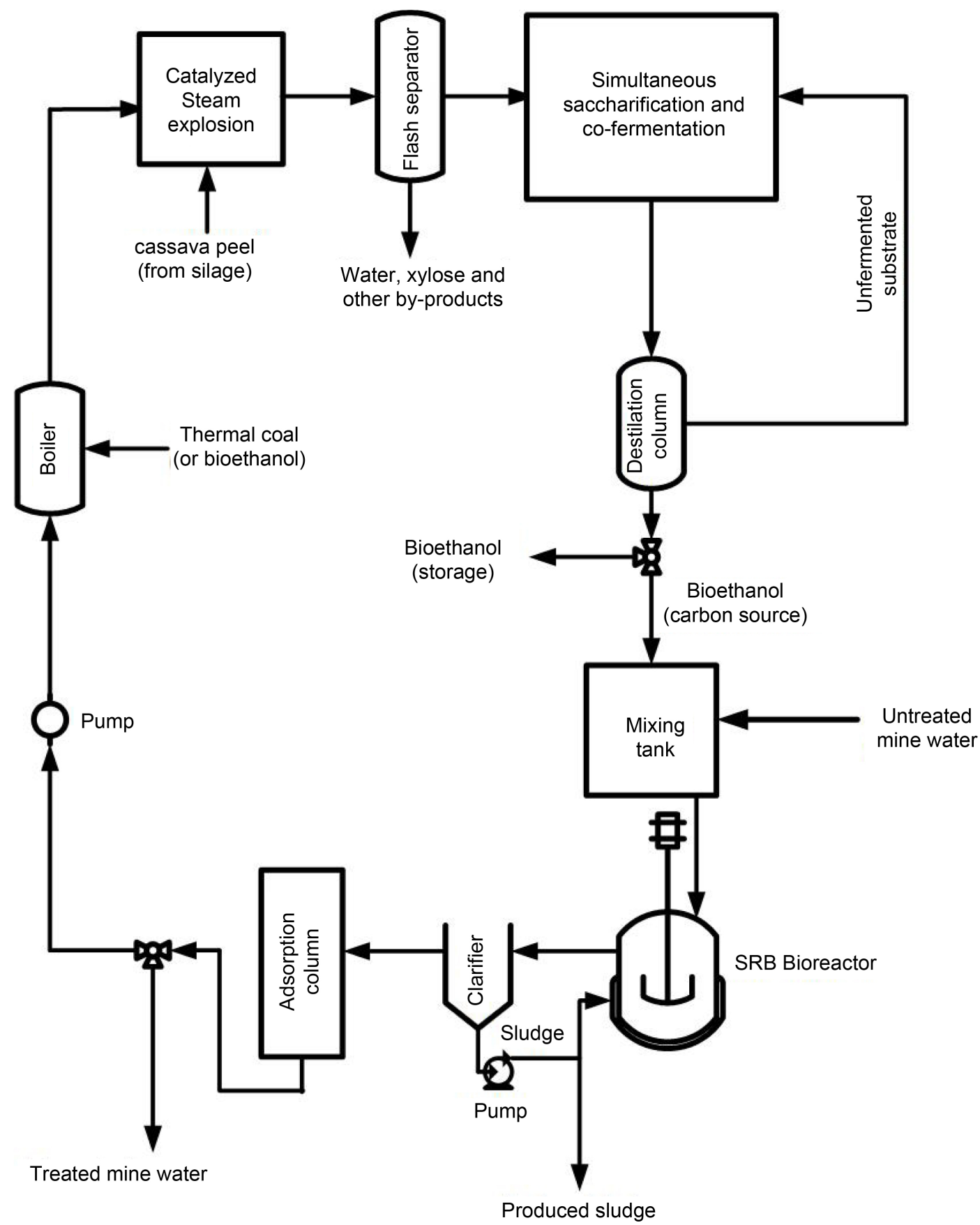

Figure 4. Production of bioethanol from cassava peel to feed SRB in the treatment of mine water. Adapted from (Adekunle, et al. 2016).

SSF would be used in the enzymatic hydrolysis to obtain high efficiency in ethanol production. After fermentation, the mixture should go to two distillation columns organized in series. In the first column, carbon dioxide that remained would be released and unreacted substrate (including unfermented sugar) would be collected and sent back to SSF. The ethanol produced with an estimated concentration of $37 \mathrm{wt} \%$ [49] would be collected and introduced in the second distillation column to increase the concentration up to $95 \mathrm{wt} \%$ [49]. Part of the produced ethanol would be collected and stored in proper reservoir and others 
would be used as carbon source for SRB. The carbon source (bioethanol) and mine water could be mixed together in a mixing tank. The mixture would be introduced in a bioreactor that was inoculated before with SRB. The treated water must be sent to a clarifier to allow precipitation of metal sulfide (sludge). Treated mine water which is rich in alkalinity $\left(\mathrm{HCO}_{3}^{-}\right)$that comes from the clarifier would be sent to adsorption column to remove calcium, magnesium and other metals that cannot form metal sulfide during bioremediation. Part of the treated mine water coming from the adsorption column would be released to the environment and other would be sent to a boiler to produce steam. Part of the produced sludge should be sent back to SRB reactor and the other part could be used to recover metals in the sludge.

\section{Discussion}

The coal mines in Moatize are inside of one of the most important river basins in Southern Africa, the Zambezi river basin. Due to climate change, the temperature is expected to rise by $0.3^{\circ} \mathrm{C}$ to $0.6^{\circ} \mathrm{C}$ per decade. This rise in temperature will have impact in the rainfall which is expected to decrease by $10 \%$ to $15 \%$ and the evaporation also is expected to decrease by $10 \%$ to $25 \%$ by 2050 . It means that Zambezi river basin will become more dry and less water will be available for mining activities, agriculture and drinking water supply for the local people [50]. Mining industry is one of the most water consuming industries in the world, and thus water must be used in sustainable way in order to avoid compromising the future generation. One way of doing that is to treat the mine water that is generated in the mines and use it for different activities inside Zambezi river basin.

According to FAO, Mozambique produced 10 million tonnes of cassava in 2012, which means that 1.5 million tonnes of cassava peel were generated. This agro-waste was just discarded. According to Vale, coal mine in Mozambique, 5 billion liters of mine water were generated inside Vale coal mine in Moatize in 2012. Only $47 \%$ of the generated mine water was recycled and the other $53 \%$ was discharged to the local environment [51]. Instead of discarding 1.5 million tonnes of cassava peel and release to the environment 2.65 billion liters of polluted mine water, it could be good to use the agro-waste to treat the polluted mine water and use the treated mine water for agriculture.

Mine water that is treated using SRB eliminates toxic metals that are able to form metal sulfide as shown in Equation (2). The metal sulfides have low solubility and thus, they can be removed through sedimentation. The disadvantage of SRB is that it cannot remove some metals $\left(\mathrm{Ca}^{2+}, \mathrm{Mg}^{2+}\right)$ because they are not able to form metal sulfide. To overcome this problem, adsorption can be coupled with SRB bioreactor to increase the treatment of mine water. Cassava peel would be used as carbon source for SRB and as adsorbent for adsorption process. The treated mine water could be used for the irrigation of native plants and crops that are produced in the Zambezi river basin. Some of the coal mines in Moatize have plans to restore the environment impacted by mining through planting na- 
tive species. For that, mine water treated with combination of SRB and adsorption can be used as irrigation water.

\section{Conclusion}

Ethanol produced from cassava peel can be used as fuel and as a carbon source for SRB. The use of ethanol as a carbon source for SRB in the treatment of mine water appears to be a good solution for polluted mine water in Moatize. There is a need to couple bioremediation with an adsorption column where the cassava peel would be used as adsorbent to remove metals that do not form metal sulfide in the bioremediation process. The treated mine water could be used for various purposes inside of the Zambezi Basin. In conclusion, applying agro-waste generated in developing countries in the treatment of mine water could be a good solution to protect the environment against pollution and also a source of water for local farmers to do agriculture.

\section{Acknowledgements}

The authors would like to thanks SIDA for providing financial support for this research and also the Lund University for providing technical support.

\section{References}

[1] Kousi, P., Remoundaki, E., Hatzikioseyian, A. and Tsezos, M. (2015) Sulphate-Reducing Bioreactors: Current Practices and Perspectives. International water Association (IWA).

[2] Simate, G.S. and Ndlovu, S. (2014) The Removal of Heavy Metals in a Packed Bed Column Using Immobilized Cassava Peel Waste Biomass. Journal of Industrial and Engineering Chemistry, 21, 635-643. https://doi.org/10.1016/j.jiec.2014.03.031

[3] Hussain, A., Hasan, A., Javid, A. and Qazi, J. (2016) Exploited Application of Sulfate-Redicing Bacteria for Concomitant Treatment of Mettalic and Non-Metallic Wastes: A Mini Review. 3 Biotech, 6, 119. https://doi.org/10.1007/s13205-016-0437-3

[4] Westholm, L.J., Repo, E. and Sillanpää, M. (2014) Filter Materials for Metal Removal from Mine Drainage-A Review. Environmental Science and Pollution Research, 21, 9109-9128. https://doi.org/10.1007/s11356-014-2903-y

[5] Gray, N. (1996) Field Assessment of Acid Mine Drainage Contamination in Surface and Ground Water. Environmental Geology, 27, 358-361. https://doi.org/10.1007/BF00766705

[6] Fungaro, D. and Izidoro, J. (2006) Remediacão da Drenagem Ácida de Mina Usando Zeólitas Sintéticas a partir de Zinzas Leves de Carvão. Química Nova, 29, 735 740. https://doi.org/10.1590/S0100-40422006000400019

[7] INE (2015) Statistical Year Book of Mazambique. Instituto Nacioal de Estatistica, Maputo.

[8] Galhardi, J.A. and Bonotto, D.M. (2016) Hydrogeochemical Features of Surface Water and Groundwater Contaminated with Acid Mine Drainage (AMD) in Coal Mining Areas: A Case Study in Southern Brazil. Environmental Science and Pollution Research, 23, 18911-18927. https://doi.org/10.1007/s11356-016-7077-3

[9] WHO (1996) Guidelines for Drinking Water Quality. World Health Organization, Geneva. 
[10] USEPA (2002) Economic Analysis of the Implementation of Permeable Reactive Barriers for Remediation of Contaminated Groundwater. Environmental Protection Agency, Washington DC.

[11] Tuppurainen, K., Väisänen, A. and Rintala, J. (2001) Sulphate-Reducing Laboratory-Scale High-Rate Anaerobic Reactors for Treatment of Metal and Sulphate-Containing Mine Wastewater. Environmental Technology, 23, 599-608. https://doi.org/10.1080/09593332308618382

[12] Wolkersdorfer, C. (2008) Water Management at Abandoned Flooded Underground Mines. International Mine Water Association, Springer, Munchen.

[13] Klein, R., Tischler, J.S., Muhling, M. and Schlömam, M. (2013) Bioremediation of Mine Water. Advanced Biochemical Engineering Biotechnology, 141, 109-172. https://doi.org/10.1007/10_2013_265

[14] Kaksonen, A. and Puhakka, J. (2007) Sulfate Reduction Based Bioprocesses for the Treatment of Acid Mine Drainage and the Recovery of Metals. Engineering in Life, 6, 541-564. https://doi.org/10.1002/elsc.200720216

[15] Contreras, J.O., Flores, D.P., Gutiérrez, P. and Crooker, P. (2015) Acid Mine Drainage in Chile: An Opportunity to Apply Bioremediation Technology. Hydrology: Current Research, 6, 215.

[16] Liamleam, W. and Annachhatre, A. (2007) Electron Donors for Biological Sulfate Reduction. Biotechnologu Advances, 25, 452-463. https://doi.org/10.1016/j.biotechadv.2007.05.002

[17] Hao, T.-W., Xiang, P.-Y., Mackey, H.R., Chi, K., Lu, H., Chui, H.-K., Loosdrecht, M.C.V. and Chen, G.-H. (2014) A review of Biological Sulfate Conversion in Wastewater Treatment. Water Research, 65, 1-21. https://doi.org/10.1016/j.watres.2014.06.043

[18] FAO (2012) Agricultural Statistics. Food and Agricultural Organization of the United Nations, Rome.

[19] Koyama, N., Kaiser, J., Ciugu, K. and Kabiru, J. (2015) Market Opportunities for Commercial Cassava in Ghana, Mozambique, and Nigeria.

[20] Edhirej, A., Sapuan, S.M., Jawaid, M. and Zahari, N.I. (2015) Cassava: Its Polymer, Fiber, Composite, and Application.

[21] Nanssou, P.A.K., Nono, Y.J. and Kapseu, C. (2016) Pretreatment of Cassava Stems and Peelings by Thermohydrolysis to Enhance Hydrolysis Yield of Cellulose in Bioethanol Production Process. Renewable Energy, 97, 252-265. https://doi.org/10.1016/j.renene.2016.05.050

[22] Babayemi, O., Ifut, O., Inyang, U. and Isac, I. (2010) Quality and Chemical Composition of Cassava Wastes Ensiled With AlbiziaSaman Pods. Agricultural Journal, 3, 225-228.

[23] Pooja, N. and Padmaja, G. (2015) Pretreatment Techniques to Enhance the Enzimatic Degradability of Agricultural and Processing Residues of Cassava. Waste Biomass Valor, 3, 303-315. https://doi.org/10.1007/s12649-015-9345-8

[24] Greben, H., Baloyi, J., Sigama, J. and Venter, S. (2009) Bioremediation of Sulphate Rich Mine Effluents Using Grass Cutting and Rumen Fluid Microorganisms. Geotechnical Exploration, 100, 163-168. https://doi.org/10.1016/j.gexplo.2008.01.004

[25] Greben, H., Maree, J. and Mnqanqeni, S. (2000) Comparison Between Sucrose, Ethanol and Methanol as Carbon and Energy Sources for Biological Sulphate Reduction. Water Science and Technology, 41, 247-253.

[26] Hu, F. and Ragauskas, A. (2012) Pretreatment and Lignocellulosonic Chemistry. Bio Energy Research, 5, 1043-1066. https://doi.org/10.1007/s12155-012-9208-0 
[27] Hu, Z., Foston, M. and Ragauskas, A. (2011) Biomass Characterization of Morphological Portion of Alamo Switchgrass. Agricultural and Food Chemistry, 59, 77657772. https://doi.org/10.1021/jf104844r

[28] Tan, K., Lee, K. and Muhamed, A. (2008) Role of Energy Policy in Renewable Energy Accomplishment: The Case of Second Generation Bioethanol. Energy Policy, 36, 3360-3365. https://doi.org/10.1016/j.enpol.2008.05.016

[29] Balat, M., Balat, H. and Öz, C. (2008) Progress in Bioethanol Processing. Progress in Energy and Combustion Science, 34, 551-573. https://doi.org/10.1016/j.pecs.2007.11.001

[30] Sun, Y. and Cheng, J. (2002) Hydrolisys of Lignocellulosonic Materials for Ethanol Production: A Review. Bioresource Technology, 83, 1-11. https://doi.org/10.1016/S0960-8524(01)00212-7

[31] Padmaja, G. (1995) Cyanide detoxication in Cassava for Food and Feed Uses. Food Science \& Nutrition, 35, 299-339.

[32] Chaoui, H. and Eckhoff, S. (2014) Biomass Feed Stock Storage for Quantity and Quality Preservation. In: Shastri, Y., Hansen, A., Rodríguez, L. and Ting, K.C., Eds., Engineering and Science of Biomass Feedstock Production and Provision, Springer, Berlin, 165-193. https://doi.org/10.1007/978-1-4899-8014-4_7

[33] Faust, S. and Aly, O. (1987) Adsorption Process for Water Treatment. Butterworth, Stoneham.

[34] Barakat, M. (2011) New Trends in Removing Heavy Metals from Industrial Wastewater. Arabian Journal of Chemistry, 4, 361-377.

https://doi.org/10.1016/j.arabjc.2010.07.019

[35] Onal, Y., Akmil-Bas, C., Sarici-Ozdemir, C. and Erdogan, S. (2007) Textural Development of Sugar Beet Bagasse Activated with $\mathrm{ZnCl}_{2}$. Hazard Material, 142, 138-143. https://doi.org/10.1016/j.jhazmat.2006.07.070

[36] Malik, D., Jain, C. and Yadav, A.K. (2016) Removal of Heavy Metals from Emerging Cellulosic Low-Cost Adsorbents: A Review. Applied Water Science, 1-24. https://doi.org/10.1007/s13201-016-0401-8

[37] Sobhanardakani, S., Parvizimosaed, H. and Olyaie, E. (2013) Heavy Metals Removal from Wastewaters Using Organic Solid Waste-Rice Husk. Environmental Science and Pollution Research, 20, 5265-5271. https://doi.org/10.1007/s11356-013-1516-1

[38] Sahu, M., Mandal, S., Dash, S., Badhai, P. and Patel, R. (2013) Removal of Pb (II) from Aqueous Solution by Acid Activated Red Mud. Journal of Environmental Chemical Engineering, 4, 1315-1324. https://doi.org/10.1016/j.jece.2013.09.027

[39] Dang, V., Doan, H., Dang-Vu, T. and Lohi, A. (2009) Equilibrium and Kinetics of Biosorption of Cadmium (II) and Coper (II) Ions by Wheat Straw. Bioresource Technology, 100, 211-219. https://doi.org/10.1016/j.biortech.2008.05.031

[40] Farinella, N., Matos, G., Lehman, E. and Arruda, M. (2008) Grape Bagasse as an Alternative Natural Adsorbent of Cadmium and Lead for Effluent Treatment. Hazard Material, 154, 1007-1012. https://doi.org/10.1016/j.jhazmat.2007.11.005

[41] Zheng, L., Zhu, C., Dang, Z., Zhang, H., Yi, X. and Liu, C. (2012) Preparation of Cellulose Derived from Corn Stalk and its Application for Cadmium Ion Adsorption from Aqueous Solution. Carbohydrates Polymers, 90, 1008-1015. https://doi.org/10.1016/j.carbpol.2012.06.035

[42] Parab, H., Joshi, S., Shenoy, N., Lali, A., Sharma, U. and Sudersaan, M. (2006) Determination of Kinetic and Equilibrium Parameters of the Batch Adsorption of Co(II) and Ni(II) Onto Coir Pith. Process Biochemistry, 41, 609-615. https://doi.org/10.1016/j.procbio.2005.08.006 
[43] Anandkumar, J. and Mandal, B. (2009) Removal of Cr(VI) from Aqueous Solution Using Bael Fruit (Aegle marmelos Correa) Shell as an Adsorbent. Hazard Material, 168, 633-640. https://doi.org/10.1016/j.jhazmat.2009.02.136

[44] Buasri, A., Chaiyut, N., Tapang, K., Jaroensin, S. and Panphrom, S. (2012) Equilibrium and Kinetic Studies of Biosorption of $\mathrm{Zn}$ (II) Ions from Wastewater Using Modified Corncob. APCBEE Procedia, 3, 60-64. https://doi.org/10.1016/j.apcbee.2012.06.046

[45] Tofan, L., Teodosiu, C., Paduraru, C. and Wenkert, R. (2013) Cobalt (II) Removal from Aqueous Solution by Natural Hemp Fibers: Batch and Fixed Bed Column Studies. Applied Surface Science, 285, 33-39.

https://doi.org/10.1016/j.apsusc.2013.06.151

[46] Schwantes, D., Goncalves, A., Coelho, G., Campagnolo, M., Dragunski, D., Tarley, C., Miola, A. and Leismann, A. (2016) Chemical Modification of Cassava Peel as Adsorbent Material for Metals Ions from Wastewater. Journal of Chemistry, 1-15. https://doi.org/10.1155/2016/3694174

[47] Mohan, D. and Chander, S. (2006) Removal and Recover of Metal Ions from Acid Mine Drainage Using Lignite-A Low Cost Sorbent. Hazard Material, 137, 15451553. https://doi.org/10.1016/j.jhazmat.2006.04.053

[48] Chockalingam, E. and Subramanian, S. (2006) Studies on Removal of Metal Ions and Sulfate Reduction Using Rice Husk and Desulfotomaculum nigrificans with Reference to Remediation of Acid Mine Drainage. Chemosphere, 62, 699-708. https://doi.org/10.1016/j.chemosphere.2005.05.013

[49] Adekunle, A., Orsat, V. and Raghavan, V. (2016) Lignocellulosic Bioethanol: A Review and Design Conceptualization Study of Production from Cassava Peels. Renewable and Sustainable Energy Reviews, 64, 518-530. https://doi.org/10.1016/j.rser.2016.06.064

[50] ZAMCOM (2015) Zambezi Environment Outlook. ZAMCOM, SADC and SARDC, Harare.

[51] Vale-Mocambique (2012) Sustentabilidade Mocambique. Vale, Maputo.

\section{Submit or recommend next manuscript to SCIRP and we will provide best service for you:}

Accepting pre-submission inquiries through Email, Facebook, LinkedIn, Twitter, etc. A wide selection of journals (inclusive of 9 subjects, more than 200 journals)

Providing 24-hour high-quality service

User-friendly online submission system

Fair and swift peer-review system

Efficient typesetting and proofreading procedure

Display of the result of downloads and visits, as well as the number of cited articles

Maximum dissemination of your research work

Submit your manuscript at: http://papersubmission.scirp.org/

Or contact jep@scirp.org 